\title{
Motivasi Memoderasi Pengaruh Pertimbangan Pasar Kerja, Lingkungan Kerja, Personalitas terhadap Minat Mahasiswa Menjadi Akuntan Publik
}

\author{
I Gede Suniantara ${ }^{1}$ \\ Fakultas Ekonomi dan Bisnis \\ Universitas Udayana, Indonesia
}

\author{
Luh Gede Krisna Dewi² \\ Fakultas Ekonomi dan Bisnis \\ Universitas Udayana, Indonesia
}

Surel : gedesuniantara1717@gmail.com

\section{ABSTRAK}

Fenomena yang terjadi saat ini di Indonesia dalam bidang akuntansi adalah kurangnya tenaga akuntan publik berdasarkan pernyataan Institut Akuntan Publik Indonesia (IAPI). Kurangnya minat mahasiswa akuntansi terhadap profesi akuntan publik menjadi salah satu akibat sedikitnya lulusan akuntansi menjadi akuntan publik. Pertimbangan pasar kerja, lingkungan kerja, personalitas serta motivasi menjadi faktor yang mempengaruhi minat mahasiswa. Penelitian ini akan mengambil populasi yaitu mahasiswa akuntansi angkatan 2017 Fakultas Ekonomi Unud. Sampel yang didapatkan setelah menggunakan metode slovin sebanyak 168 mahasiswa. Moderated Regression Analysis (MRA) digunakan sebagai teknik analisis penelitian ini. Hasil penelitian ini yaitu membuktikan bahwa pertimbangan pasar kerja, lingkungan kerja, personalitas dan motivasi berpengaruh terhadap minat mahasiswa akuntansi menjadi akuntan publik.

Kata Kunci: Pertimbangan Pasar Kerja; Lingkungan Kerja; Personalitas; Motivasi; Minat.

\section{Motivation as a Moderating the Effect of Considerations Labor Market, Work Environment and Personality on the Interest of Accounting Students to be Public Accountant}

\section{ABSTRACT}

The current phenomenon in Indonesia in the accounting sector is the lack of public accountants based on a statement from the Indonesian Institute of Certified Public Accountants (IAPI). The lack of interest in accounting students towards the public accounting profession is one of the results of the lack of accounting graduates becoming public accountants. Considerations of the labor market, work environment, personality and motivation are factors that influence student interest. This study will take a population, namely accounting students class 2017, Faculty of Economics, Udayana University. The samples obtained after using the Slovin method were 168 students. Moderated Regression Analysis (MRA) was used as the analysis technique for this study. The results of this study prove that considerations of the job market, work environment, personality and motivation affect the interest of accounting students to become public accountants.

Keywords: Considerations Labor Market; Work Environment; Personality, Motivation; Interests.

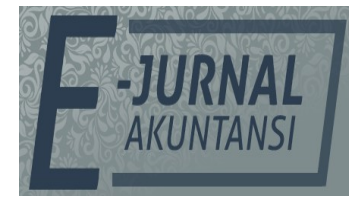

e-ISSN 2302-8556

Vol. 31 No. 8

Denpasar, Agustus 2021 Hal. 1947-1959

DOI:

10.24843/EJA.2021.v31.i08.p06

PENGUTIPAN:

Suniantara, I.G., \& Dewi, L.G.K. (2021). Motivasi

Memoderasi Pengaruh Pertimbangan Pasar Kerja, Lingkungan Kerja,

Personalitas terhadap Minat Mahasiswa Menjadi Akuntan Publik. E-Jurnal Akuntansi, 31(8), 1947-1959

RIWAYAT ARTIKEL: Artikel Masuk: 18 Desember 2020 Artikel Diterima: 19 Februari 2021

Artikel dapat diakses : https://ojs.unud.ac.id/index.php/Akuntansi/index 


\section{PENDAHULUAN}

Institut Akuntan Publik Indonesia (IAPI) menyatakan bahwa saat ini tenaga akuntan publik di Indonesia masih kurang Keadaan tersebut disebabkan salah satunya karena kurangnya minat mahasiswa yang setelah lulus sarjana untuk berprofesi sebagai akuntan publik (Paramita \& Sari, 2019). Faktor-faktor yang mempengaruhi pemilihan karir mahasiswa dan jenis karir yang akan mereka jalani merupakan hal menarik untuk diteliti karena dengan diketahuinya pilihan karir yang diminati mahasiswa maka dapat diketahui mengapa sesorang memilih karir tersebut sesuai dengan penelitian Ng et al. (2017), Owusu et al (2018) dan Hatane et al (2020). Khususnya dalam memilih karir sebagai akuntan publik akan menjadi hal penting mengingat Indonesia masih memerlukan tenaga akuntan publik yang cukup banyak.

Pertimbangan pasar kerja berhubungan erat dengan pekerjaan yang dapat diakses di masa yang akan datang. Pekerjaan yang memiliki pasar kerja yang lebih luas akan lebih diminati daripada pekerjaan yang pasar kerjanya kecil (Aziz et al, 2017) dan (Caza et al 2015). Pertimbangan pasar kerja selalu dipertimbangkan mahasiswa dalam pemilihan profesi, karena terpuruknya keadaan perekonomian dan sulitnya mencari kerja mengakibatkan mahasiswa memperhatikan pasar kerja, baik dalam jangka panjang maupun jangka pendek (Rahayu \& Putra, 2019).

Lingkungan kerja menjadi perhatian bagi mahasiswa untuk menyesuaikan diri dalam memilih karir nantinya sesuai dengan kemampuan yang dimiliki (Dalc1 \& Hasan, 2018) dan (Muhamad et al, 2016). Lingkungan kerja dipertimbangkan dalam pemilihan profesi oleh mahasiswa terutama pada sifat pekerjaan rutin yang akan dijalani nantinya (Juliansah \& Suryaputri, 2016). Mahasiswa melihat profesi akuntan publik merupakan jenis pekerjaan yang tidak rutin, tetapi banyak tantangan dan tidak dapat dengan cepat terselesaikan (Wen et al, 2018).

Personalitas merupakan salah satu determinan yang potensial terhadap perilaku individu saat berhadapan dengan situasi atau kondisi tertentu. Hal ini membuktikan bahwa personalitas berpengaruh terhadap perilaku seseorang. Berdasarkan penelitian Hastuti \& Kartika (2017) dan Farag \& Elias (2016) personalitas dapat menunjukkan bagaimana mengendalikan atau mencerminkan kepribadian seseorang dalam bekerja.

Beberapa hasil penelitian mengenai tiga faktor tersebut menyatakan hasil yang berbeda atau terjadi inkonsistensi. Hal ini menyebabkan terdapat faktor lain yang mempengaruhi persepsi mahasiswa dalam menentukan karirnya. Faktor tersebut tidak lain adalah dari dalam diri mahasiswa sendiri dalam bentuk sebuah motivasi (Irma \& Hartati, 2019). Motivasi merupakan akibat dari suatu hasil yang ingin dicapai oleh seseorang dari hal yang bersangkutan bahwa tindakan yang akan diambil atau sesuatu yang diekspetasi akan mengarah kepada hasil yang diinginkannya sesuai dengan keadaan yang dimiliki (Ahmad et al, 2015). Hal ini menjadi salah satu hal yang mempengaruhi bagaimana mahasiswa akan menentukan pola pikir dalam menyikapi faktor-faktor penentuan karir tersebut. Motivasi dalam diri mahasiswa akan menjadi faktor untuk memperkuat pilihannya ataupun sebaliknya.

Ladasan teori digunakan untuk membuktikan sebuah penelitian (Schoenfeld et al, 2017). Penelitian ini menggunakan dua pendekatan teori yaitu Teori Perilaku Terencana dan Teori Pengharapan. Dalam Teori Perilaku 
Terencana/ Theory of Planned Behavior (TPB) yang dikembangkan oleh Ajzen (1991), teori perilaku terencana adalah pendekatan perilaku yang ditampilkan oleh individu yang timbul karena adanya intensi atau niat untuk berperilaku. Teori ini mengansumsi bahwa kontrol persepsi perilaku (perceived behavioral control) mempunyai implikasi motivasional terhadap minat (Lukman \& Winata, 2017). Sedangkan teori pengharapan menjelaskan kecenderungan untuk bertindak dengan suatu cara tertentu tergantung pada kekuatan atau pengharapan bahwa tindakan tersebut akan diikuti oleh suatu hal tertentu bagi setiap individu (Robbins \& Judge, 2017).

Adanya pertimbangan pasar kerja menjadi sebuah bahan pertimbangan dalam mendorong minat mahasiswa akuntansi untuk memilih karir sebagai akuntan khususnya akuntan publik (Dewayani et al, 2017). Pertimbangan pasar kerja membuat sebuah kondisi di mana satu atau lebih pekerjaan terbuka untuk dicari karena memang dibutuhkan pada waktu tertentu. Jika dilakukan pendekatan menggunakan teori perilaku terencana dan teori pengharapan maka mahasiswa cenderung akan merasa memiliki harapan sesuai dengan kemampuan yang dimiliki berdasarkan pertimbangan pasar kerja yang ada. Hal inilah yang mengakibatkan mahasiswa berencana untuk memilih karir yang sesuai dan memiliki minat yang bergantung pada latar belakangan kemampuan mereka apakah sesuai dengan pertimbangan pasar kerja yang ada.

$\mathrm{H}_{1}$ : Semakin tinggi pertimbangan pasar kerja yang ada maka semakin tinggi minat mahasiswa akuntansi menjadi akuntan publik.

Lingkungan kerja yang tidak kondusif dapat menyebabkan ketidakpuasan kerja. Menurut Chatman (1989) pekerjaan yang tidak sesuai dengan lingkungan nyaman menurut individu dapat meningkatkan ketidakpuasan kerja. Hal tersebut diakibatkan karena jika rutinitas yang terjadi dalam pekerjaan tidak sesuai dengan keinginin seseorang maka hal tersebut akan membuat semangat kerja menurun, sesuai dengan penelitian Kirstein et al, (2019) ini akan mempengaruhi persepsi mereka terhadapa profesi akuntan publik. Jika dilakukan pendekatan menggunakan teori perilaku terencana dan teori pengharapan maka mahasiswa akan berpikir dua kali untuk memilih pekerjaan dengan mempertimbangkan bagaimana lingkungan kerja suatu profesi yang akan mereka cari. Sehingga mereka akan memiliki rencana ke depan dengan mencari informasi dan membuat sebuah persepsi terhadap lingkungan kerja pada profesi akuntan publik.

$\mathrm{H}_{2}$ : Semakin kondusif lingkungan kerja yang ada maka semakin tinggi minat mahasiswa akuntansi menjadi akuntan publik.

Personalitas merupakan salah satu determinan yang potensial terhadap perilaku individu saat berhadapan dengan situasi atau kondisi tertentu. Hal ini menjelaskan bahwa personalitas berpengaruh terhadap perilaku. Personalitas menunjukkan bagaimana mengendalikan atau mencerminkan kepribadian seseorang dalam bekerja (Kudadiri \& Hek, 2018). Dengan menggunakan pendekatan teori perilaku terencana dan teori pengharapan, maka ini sangat jelas akan mempengaruhi minat mahasiswa akuntansi nantinya berdasarkan kondisi personal atau karakter mereka masing-masing yang akan mendorong rencana mereka ke depan untuk menentukan minat mereka. Sebuah harapan yang sesuai dengan potensi seseorang akan mengakibatkan minat seseorang tersebut semakin tertarik dengan situasi yang diberikan seperti pilihan karir. 
$\mathrm{H}_{3}$ : Semakin sesuai kondisi yang ada dengan personalitas maka semakin tinggi minat mahasiswa akuntansi menjadi akuntan publik.

Motivasi merupakan akibat dari suatu hasil yang ingin dicapai oleh seseorang dari perkiraan yang bersangkutan bahwa tindakannya akan mengarah kepada hasil yang diinginkannya (Bailey \& Phillips, 2016). Hal ini mengakibatkan motivasi menjadi faktor seseorang untuk melakukan sesuatu dan meyakini sebuah persepsi yang ada (Ulfah et al, 2019). Faktor-faktor yang memiliki pengaruh terhadap minat mahasiswa untuk memilih karir akan disesuaikan dengan motivasi yang dimiliki seseorang apakah akan mempertimbangkan persepsinya kembali atau tidak. Secara logika ketika seseorang memiliki motivasi tinggi maka daya juang untuk mewujudkan sesuatu hal tersebut akan semakin meningkat (Sina, 2014).

$\mathrm{H}_{4}$ : Semakin tinggi pertimbangan pasar kerja maka semakin tinggi minat mahasiswa akuntansi menjadi akuntan publik terutama yang memiliki motivasi tinggi.

Motivasi merupakan akibat dari suatu hasil yang ingin dicapai oleh seseorang dari perkiraan yang bersangkutan bahwa tindakannya akan mengarah kepada hasil yang diinginkannya (Bailey \& Phillips, 2016). Hal ini mengakibatkan motivasi menjadi faktor seseorang untuk melakukan sesuatu dan meyakini sebuah persepsi yang ada. Lingkungan kerja yang memiliki pengaruh terhadap minat mahasiswa untuk memilih karir akan disesuaikan dengan motivasi yang dimiliki seseorang apakah akan mempertimbangkan persepsinya kembali atau tidak. Motivasi yang akan timbul dari dalam diri seseorang akan lebih memberikan dorongan untuk mencapai keinginan yang dikehendakinya (Paramita \& Sari, 2019).

$\mathrm{H}_{5}$ : Semakin kondusif lingkungan kerja maka semakin tinggi minat mahasiswa akuntansi menjadi akuntan publik terutama yang memiliki motivasi tinggi.

Motivasi merupakan akibat dari suatu hasil yang ingin dicapai oleh seseorang dari perkiraan yang bersangkutan bahwa tindakannya akan mengarah kepada hasil yang diinginkannya (Bailey \& Phillips, 2016). Hal ini mengakibatkan motivasi menjadi faktor seseorang untuk melakukan sesuatu dan meyakini sebuah persepsi yang ada. Personalitas yang memiliki pengaruh terhadap minat mahasiswa untuk memilih karir akan disesuaikan dengan motivasi yang dimiliki seseorang apakah akan mempertimbangkan persepsinya kembali atau tidak. Kuatnya motivasi yang dimiliki individu akan banyak menentukan kualitas perilaku yang ditampilkannya dalam mencapai tujuan yang telah diharapkan (Rahayu \& Putra, 2019).

$\mathrm{H}_{6}$ : Semakin sesuai kondisi yang ada dengan personalistas maka semakin tinggi minat mahasiswa akuntansi menjadi akuntan publik terutama yang memiliki motivasi tinggi.

Penelitian ini memiliki tiga variabel independen (bebas) dan satu variabel dependen (terikat) serta satu variabel moderating (moderasi). Pertimbangan Pasar Kerja sebagai variabel independen pertama (X1), Lingkungan Kerja sebagai variabel independen kedua $(\mathrm{X} 2)$, dan Personalitas sebagai variabel independen ketiga (X3) serta Motivasi sebagai variabel moderasi (M1). Adapun variabel dependen dari peneltian ini adalah Minat Mahasiswa Akuntansi Menjadi Akuntan 
Publik (Y). Gambar 1, menunjukkan pengaruh variabel-variabel independen dan moderating terhadap variabel dependen.

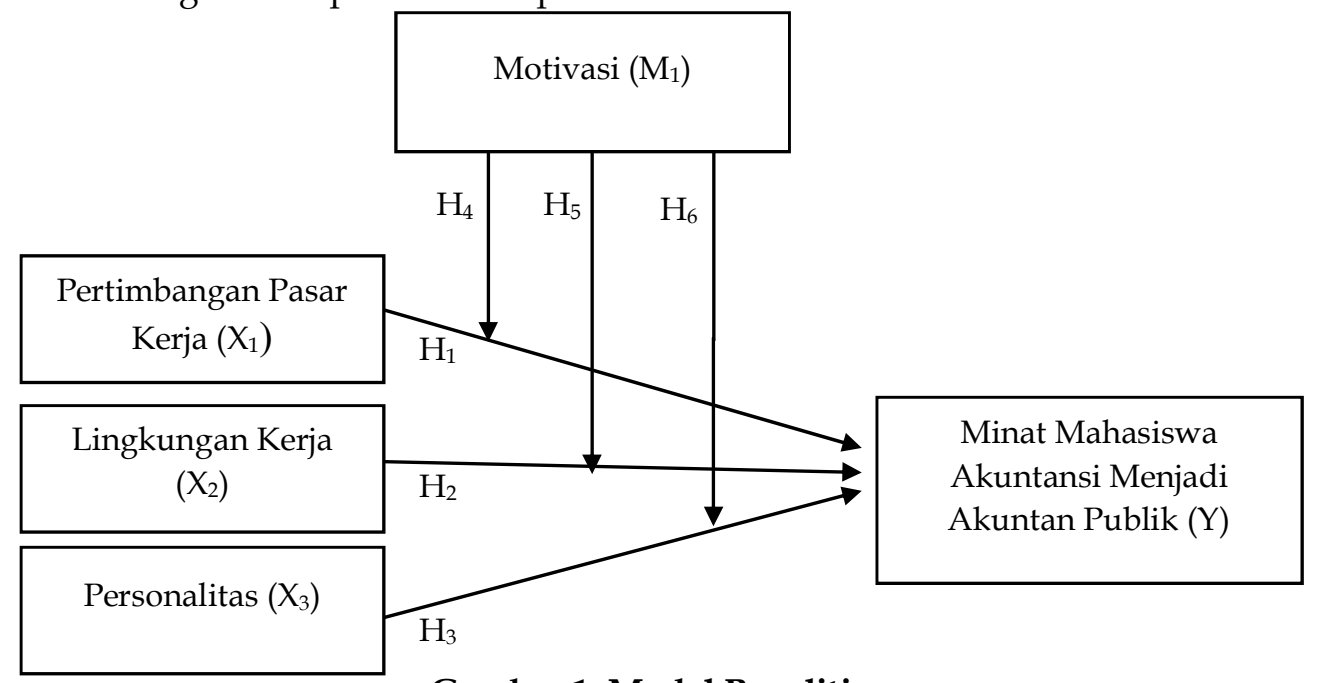

Sumber: Data Penelitian, 2020

\section{METODE PENELITIAN}

Penelitian ini menggunakan metode penyebaran kuesioner, yang berarti peneliti terlibat langsung dalam pengamatan (Sugiyono, 2017). Pengumpulan data diperoleh dari sumber data primer berupa kuesioner dari responden. Penelitian ini menggunakan pendekatan kuantitatif berbentuk asosiatif karena menguji dua variabel atau lebih (Sugiyono, 2017). Penelitian ini dilakukan untuk mengetahui pengaruh pertimbangan pasar kerja, lingkungan kerja dan personalitas terhadap minat mahasiswa akuntansi menjadi akuntan publik serta peran motivasi sebagai pemoderasi. Objek dalam penelitian ini adalah minat mahasiswa akuntansi Fakultas Ekonomi Universitas Udayana.

Populasi penelitian ini adalah seluruh mahasiswa akuntansi angkatan 2017 Fakultas Ekonomi Unud. Sampel terdiri atas jumlah anggota yang dipilih dari populasi (Sugiyono, 2017). Sampel dalam penelitian ini berjumlah 168 mahasiswa yang didapat dari metode slovin. Variabel bebas dalam penelitian ini adalah pertimbangan pasar kerja $\left(X_{1}\right)$, lingkungan kerja $\left(X_{2}\right)$, dan personalitas $\left(X_{3}\right)$. Untuk variabel moderasi adalah motivasi $(\mathrm{M})$ serta variabel terikat adalah minat mahasiswa akuntansi menjadi akuntan publik (Y).

Pasar kerja merupakan sarana yang mengkoordinasikan pertemuan antara pencari kerja dan perusahaan yang memerlukan tenaga kerja. Pasar kerja merupakan sarana tempat pertemuan antara penjual dan pembeli tenaga kerja (Irnasiwi, 2015). Pertimbangan pasar kerja adalah kondisi di mana satu atau lebih pekerjaan dibutuhkan pada waktu tertentu. Indikator pertimbangan pasar kerja menurut Wheeler (1983), meliputi tersedianya lapangan kerja, keamanan kerja, fleksibilitas karier, dan kesempatan promosi.

Lingkungan kerja merupakan gambaran suasana sebuah pekerjaan. Sebagai contoh profesi akuntan publik terdapat banyak pekerjaan yang memiliki rutinitas tertentu sehingga mempengaruhi kondisi kerja profesi tersebut (Saputra, 2011). 
Lingkungan kerja dapat membuat persepsi seseorang atas kenyamanan akan suatu pekerjaan atau tidak. Indikator lingkungan kerja menurut Alex (2000:159) meliputi suasana kerja, hubungan dengan rekan kerja dan tersedianya fasilitas kerja.

Personalitas merupakan salah satu determinan yang potensial terhadap perilaku individu saat berhadapan dengan situasi atau kondisi tertentu. Hal ini menjelaskan bahwa personalitas berpengaruh terhadap perilaku seseorang melalui kesesuaian karakter yang dimiliki (Suyono, 2014). Indikator personalitas menurut Mazli (2006), meliputi keperibadian dan karakteristik psikologi.

Minat mahasiswa akuntansi menjadi akuntan publik adalah suatu ketertarikan individu terhadap profesi akuntan publik yang menjadi sumber motivasi untuk selalu memusatkan perhatiannya akan hal tersebut. Indikator yang digunakan adalah, minat pribadi untuk berkarir menjadi akuntan publik, minat situasi untuk berkarir menjadi akuntan publik, dan minat dalam ciri psikologis untuk berkarir menjadi akuntan publik (Dwisantoso, 2017).

Motivasi merupakan akibat dari suatu hasil yang ingin dicapai oleh seseorang dari perkiraan yang bersangkutan bahwa tindakannya akan mengarah kepada hasil yang diinginkannya. Artinya, apabila seseorang sangat menginginkan sesuatu, dan jalan nampaknya terbuka untuk memperolehnya serta sesuai dengan kemampuan dan sumber daya yang dimiliki, maka yang bersangkutan akan berupaya mendapatkannya (Dewayani et al., 2017). Indikator motivasi menurut Robbins \& Judge (2017), meliputi upaya, kinerja dan imbalan.

Teknik analisis data dalam penelitian ini menggunakan Moderated Regression Analysis (MRA) dengan melakukan uji asumsi klasik terlebih dahulu yaitu uji normalitas, heterokedastisitas dan uji multikolinearitas. Penelitian ini juga melakukan uji koefisien determinasi (Adjusted $\left.\mathrm{R}^{2}\right)$, uji kelayakan model $\left(\mathrm{F}_{\text {test }}\right)$, dan uji hipotesis (t-test). Adapun persamaan umum regresi sebagai berikut.

$Y=\alpha+\beta_{1} X_{1}+\beta_{2} X_{2}+\beta_{3} X_{3}+\beta_{4} M+\beta_{5} X_{1} M+\beta_{6} X_{2} M+\beta_{7} X_{3} M+\varepsilon$

\section{HASIL DAN PEMBAHASAN}

Fakultas Ekonomi Universitas Udayana didirikan pada awal tahun 1967 dan disahkan dengan S.K. Dirjen Pendidikan Tinggi No. 102 tanggal 2 September 1967. Pada saat berdirinya, Fakultas Ekonomi Universitas Udayana hanya diperkenankan melaksanakan pendidikan Sarjan Muda. Surat keputusan tersebut berlaku hingga tahun 1976, dimana pada saat itu Fakultas Ekonomi Universitas Udayana mulai diperkenankan melaksanakan pendidikan Sarjana Lengkap Ekonomi. Keputusan tentang pendidikan Sarjana Lengkap Ekonomi tersebut dituangkan dalam S.K. Menteri Pendidikan dan Kebudayaan No. 0138/8/1976 tanggal 18 Juni 1976. Sejak tahun 1980 pendidikan Sarjana Lengkap ini disebut Strata Satu (S1).

Program S1 Jurusan Akuntansi bertujuan untuk menghasilkan sarjana ekonomi yang memiliki keahlian di bidang akuntansi dan mampu menduduki jabatan sebagai tenaga professional di bidang akuntansi. Selain itu, dengan adanya program S1 Jurusan Akuntansi diharapkan juga dapat membantu dalam memnuhi permintaan perusahaan akan sumber daya manusia yang memiliki kualitas pendidikan yang bermutu. Khususnya di bidang akuntan publik yang masih kurang di Indonesia sehingga lulusan sarjana akuntansi Universitas 
Udayana diharapkan mampu memberikan kontribusi untuk mengisi kekurangan tenaga akuntan publik dengan kualitas yang baik.

Berkaitan dengan pembahasan sebelumnya, maka dilakukan penelitian mengenai motivasi sebagai pemoderasi pengaruh pertimbangan pasar kerja, lingkungan kerja, dan personalitas terhadap minat mahasiswa akuntansi menjadi akuntan publik guna memberikan gambaran mengenai faktor apa saja yang dapat mempengaruhi minat mahasiswa akuntansi menjadi akuntan publik. Sehingga diharapkan kedepannya baik mahasiswa maupun penyelengara pendidikan dapat berfokus pada upaya guna meningkatan kualitas mahasiswa Fakultas Ekonomi dan Bisnis Universitas Udayana khususnya Program Studi S1 Akuntansi dan memberi dorongan untuk menjadi tenaga akuntan publik.

Tabel 1. Hasil Seleksi Pemilihan Sampel

\begin{tabular}{lcc}
\hline & Keterangan & $\begin{array}{c}\text { Jumlah } \\
\text { (orang) }\end{array}$ \\
\hline Populasi & Mahasiswa program studi S1 akuntansi reguler bukit \\
Kriteria & $\begin{array}{c}\text { Metode Slovin } \\
\text { dan denpasar angkatan } 2017\end{array}$ & $(168)$ \\
& Total yang dijadikan sampel & 168 \\
\hline
\end{tabular}

Sumber: Data Penelitian, 2020

Penelitian ini menggunakan sampel yang memenuhi kriteria- kriteria pemilihan sampel yang telah ditentukan sebelumnya. Berdasarkan observasi penelitian, dari jumlah populasi mahasiswa akuntansi reguler bukit dan Denpasar angkatan 2017 yang berjumlah masing-masing 151 dan 138 orang, yang akan dijadikan sampel adalah sebanyak 168 orang, dengan proses seleksi yang ditunjukkan pada Tabel 1, sebagai berikut.

Tabel 2. Hasil Statistik Deskriptif

\begin{tabular}{cccccc}
\hline Variabel & N & Minimum & Maximum & Mean & $\begin{array}{c}\text { Std. } \\
\text { Devitiation }\end{array}$ \\
\hline Pertimbangan pasar kerja & 168 & 9 & 20 & 15,89 & 2,383 \\
Lingkungan kerja & 168 & 11 & 16 & 13,93 & 1,731 \\
Personalitas & 168 & 4 & 16 & 13,19 & 1,994 \\
Motivasi & 168 & 16 & 24 & 21,35 & 2,491 \\
Minat mahasiswa & 168 & 6 & 24 & 18,26 & 3,777 \\
\hline
\end{tabular}

Sumber: Data Penelitian, 2020

Pertimbangan pasar kerja $\left(X_{1}\right)$ memiliki nilai rata-rata (mean) sebesar 15,89 , artinya ada kecenderungan mendekati nilai maksimum atau mengindikasikan bahwa jawaban atas pertimbangan pasar kerja oleh mahasiswa cenderung tinggi. Nilai standar deviasi pertimbangan pasar kerja sebesar 2,383, lebih rendah dibandingkan nilai rata-rata. Hal ini menunjukkan bahwa sebaran data berupa jawaban responden pada butir-butir pernyataan pertimbangan pasar kerja dapat dinyatakan sudah merata atau rentang data satu dengan yang lainnya tidak tergolong tinggi.

Lingkungan kerja $\left(X_{2}\right)$ memiliki nilai rata-rata (mean) sebesar 13,93, artinya ada kecenderungan mendekati nilai maksimum atau mengindikasikan bahwa jawaban atas lingkungan kerja oleh mahasiswa cenderung tinggi. Nilai standar deviasi pertimbangan pasar kerja sebesar 1,731, lebih rendah dibandingkan nilai rata-rata. Hal ini menunjukkan bahwa sebaran data berupa jawaban responden 
pada butir-butir pernyataan lingkungan kerja dapat dinyatakan sudah merata atau rentang data satu dengan yang lainnya tidak tergolong tinggi.

Personalitas $\left(X_{3}\right)$ memiliki nilai rata-rata (mean) sebesar 13,19 , artinya ada kecenderungan mendekati nilai maksimum atau mengindikasikan bahwa jawaban atas personalitas oleh mahasiswa cenderung tinggi. Nilai standar deviasi pertimbangan pasar kerja sebesar 1,994, lebih rendah dibandingkan nilai rata-rata. Hal ini menunjukkan bahwa sebaran data berupa jawaban responden pada butirbutir pernyataan personalitas dapat dinyatakan sudah merata atau rentang data satu dengan yang lainnya tidak tergolong tinggi.

Motivasi (M) memiliki nilai rata-rata (mean) sebesar 21,35, artinya ada kecenderungan mendekati nilai maksimum atau mengindikasikan bahwa jawaban atas motivasi oleh mahasiswa cenderung tinggi. Nilai standar deviasi pertimbangan pasar kerja sebesar 2,491, lebih rendah dibandingkan nilai rata-rata. Hal ini menunjukkan bahwa sebaran data berupa jawaban responden pada butirbutir pernyataan motivasi dapat dinyatakan sudah merata atau rentang data satu dengan yang lainnya tidak tergolong tinggi.

Minat mahasiswa menjadi akuntan publik $(Y)$ memiliki nilai rata-rata (mean) sebesar 18,26, artinya ada kecenderungan mendekati nilai maksimum atau mengindikasikan bahwa jawaban atas minat mahasiswa menjadi akuntan publik oleh mahasiswa cenderung tinggi. Nilai standar deviasi pertimbangan pasar kerja sebesar 3,777, lebih rendah dibandingkan nilai rata-rata. Hal ini menunjukkan bahwa sebaran data berupa jawaban responden pada butir-butir pernyataan minat mahasiswa menjadi akuntan publik dapat dinyatakan sudah merata atau rentang data satu dengan yang lainnya tidak tergolong tinggi.

Tabel 3. Hasil Uji Normalitas

\begin{tabular}{cc}
\hline & Unstandardized Residual \\
\hline $\mathrm{N}$ & 168 \\
Kolmogorov-Smirnov Z & 0,068 \\
Asymp. Sig. (2-tailed) & 0,054 \\
\hline
\end{tabular}

Sumber: Data Penelitian, 2020

Data penelitian yang digunakan dikatakan berdistribusi normal apabila nilai Asymp.Sig (2-tailed) lebih besar dari $\alpha=0,05$. Berdasarkan Tabel 3, nilai Asymp.Sig (2-tailed) dari model persamaan yang diuji sebesar 0,054 lebih besar dari 0,05. Hal ini menunjukan data yang digunakan dalam penelitian ini telah berdistribusi normal.

Tabel 4. Hasil Uji Multikolonearitas

\begin{tabular}{lcc}
\hline \multirow{2}{*}{ Variabel } & \multicolumn{2}{c}{ Collinearity Statistic } \\
\cline { 2 - 3 } & Tolerance & VIF \\
\hline Pertimbangan pasar kerja $\left(\mathrm{X}_{1}\right)$ & 0,820 & 1,219 \\
Lingkungan kerja $\left(\mathrm{X}_{2}\right)$ & 0,825 & 1,212 \\
Personalitas $\left(\mathrm{X}_{3}\right)$ & 0,792 & 1,262 \\
Motivasi $(\mathrm{M})$ & 0,761 & 1,315 \\
\hline Sun & &
\end{tabular}

Sumber: Data Penelitian, 2020

Hasil pengujian SPSS pada Tabel 4, menunjukan bahwa variabel bebas dalam model regresi tidak saling berkorelasi. Diperoleh nilai VIF untuk masing masing variabel bebas kurang dari 10 dan nilai tolerance berada diatas 0,1 maka 
dapat disimpulkan bahwa tidak adanya multikolinearitas antara variabel bebas dalam model regresi.

Tabel 5. Hasil Uji Heterokedastisitas

\begin{tabular}{lc}
\hline \multicolumn{1}{c}{ Variabel } & Sig. \\
\hline Pertimbangan pasar kerja $\left(\mathrm{X}_{1}\right)$ & 0,473 \\
Lingkungan kerja $\left(\mathrm{X}_{2}\right)$ & 0,060 \\
Personalitas $\left(\mathrm{X}_{3}\right)$ & 0,409 \\
Motivasi $(\mathrm{M})$ & 0,312 \\
\hline
\end{tabular}

Motivasi (M)

Sumber: Data Penelitian, 2020

Berdasarkan Tabel 5, dapat dilihat signifikasi lebih tinggi dari tingkat kepercayaan 0,05. Oleh karena itu, dapat dikatakan tidak terjadi gejala heteroskedastisitas pada data dengan variabel dependen minat mahasiswa akuntansi menjadi akuntan publik.

Tabel 6. Hasil Uji Moderated Regression Analysis (MRA)

\begin{tabular}{ccccccc}
\hline \multirow{2}{*}{ Model } & \multicolumn{2}{c}{ Unstandardized Coefficients } & $\begin{array}{c}\text { Standardizert } \\
\text { Coefficient }\end{array}$ & \multirow{2}{*}{$\mathrm{t}$} & \multirow{2}{*}{ Sig } \\
\cline { 3 - 5 } & & $\mathrm{B}$ & Std.Erorr & Beta & & \\
\hline 1 & (Constant) & 23,420 & 5,581 & & 4,197 & 0,000 \\
& X1 & 0,334 & 0,141 & 0,261 & 2,366 & 0,019 \\
X2 & 2,709 & 0,547 & 1,237 & 4,952 & 0,000 \\
& X3 & 1,051 & 0,286 & 0,611 & 3,678 & 0,000 \\
& X1*M & 0,002 & 0,397 & 0,223 & 0,306 & 0,760 \\
& X2*M & 0,103 & 0,024 & 1,713 & 4,334 & 0,000 \\
& X3*M & 0,029 & 0,014 & 0,516 & 2,128 & 0,035 \\
\hline
\end{tabular}

Sumber: Data Penelitian, 2020 berikut.

Dari hasil analisis MRA pada Tabel 6, dapat dibuat persamaan sebagai

$$
\mathrm{Y}=23,420+0,0334 \mathrm{X}_{1}+2,709 \mathrm{X}_{2}+1,051 \mathrm{X}_{3}+0,002 \mathrm{X}_{1} * \mathrm{M}+0,103 \mathrm{X}_{2} * \mathrm{M}+0,029 \mathrm{X}_{3}{ }^{*} \mathrm{M}+\varepsilon
$$

Nilai $\alpha$ sebesar 23,420 berarti apabila $X_{1}, X_{2}, X_{3}, X_{4}, X_{5}, X_{6}$, dan $X_{7}$ bernilai 0 , maka minat mahasiswa akuntansi menjadi akuntan publik meningkat sebesar 23,420 satuan. Nilai $\beta_{1}$ sebesar 0,0334 berarti $X_{1}$ meningkat sebesar 1 satuan dengan anggapan variabel lainnya konstan, maka $\mathrm{Y}$ akan meningkat sebesar 0,0334 satuan. Nilai $\beta_{2}$ sebesar 2,709 berarti $X_{2}$ meningkat sebesar 1 satuan dengan anggapan variabel lainnya konstan, maka $Y$ akan meningkat sebesar 2,709 satuan. Nilai $\beta_{3}$ sebesar 1,051 berarti $X_{3}$ meningkat sebesar 1 satuan dengan anggapan variabel lainnya konstan, maka $Y$ akan meningkat sebesar 1,051 satuan. Nilai $\beta_{4}$ sebesar 0,002 berarti $\mathrm{X}_{1}{ }^{*} \mathrm{M}$ meningkat sebesar 1 satuan dengan anggapan variabel lainnya konstan, maka $Y$ akan meningkat sebesar 0,002 satuan. Nilai $\beta_{5}$ sebesar 0,103 berarti $\mathrm{X}_{4}{ }^{*} \mathrm{M}$ meningkat sebesar 1 satuan dengan anggapan variabel lainnya konstan, maka $Y$ akan meningkat sebesar 0,103 satuan. Nilai $\beta_{6}$ sebesar 0,029 berarti $\mathrm{X}_{5}{ }^{*} \mathrm{M}$ meningkat sebesar 1 satuan dengan anggapan variabel lainnya konstan, maka Y akan meningkat sebesar 0,029 satuan.

Tabel 7. Hasil Koefisien Determinasi $\left(\mathbf{R}^{2}\right)$

\begin{tabular}{ccccc}
\hline Model & $\mathrm{R}$ & $R$ Square & Adjusted $\mathrm{R}$ Square & $\begin{array}{c}\text { Std. Error of the } \\
\text { Estimate }\end{array}$ \\
\hline 1 & 0,636 & 0,404 & 0,378 & 2,898 \\
\hline
\end{tabular}

Sumber: Data Penelitian, 2020 
Dari Tabel 7, menunjukan bahwa nilai Adjusted $\mathrm{R}^{2}$ adalah sebesar 0,404 berarti bahwa variasi variabel independen mampu menjelaskan $40,4 \%$ variasi variabel dependen, sedangkan sisanya yaitu sebesar 59,6\% dijelaskan oleh variabel lain diluar variabel independen.

Tabel 8. Hasil Uji Kelayakan Model (F)

\begin{tabular}{ccccccc}
\hline & Model & Sum of Squares & $d f$ & Mean Square & F & Sig \\
\hline 1 & Regression & 970,288 & 7 & 138,613 & 15,517 & 0,000 \\
& Residual & 1429,229 & 160 & 8,933 & & \\
Total & 2399,518 & 167 & & & \\
& & & & & & \\
&
\end{tabular}

Sumber: Data Penelitian, 2020

Tabel 9, menunjukan bahwa nilai $\mathrm{F}_{\text {hitung }}$ sebesar 15,517 dengan signifikansi $\mathrm{F}$ sebesar 0,000 yang lebih kecil dari nilai a $=0,05$ maka menunjukan bahwa model Moderated Regression Analysis (MRA) layak digunakan sebagai alat analisis dalam penelitian ini.

Tabel 9. Hasil Uji Hipotesis

\begin{tabular}{lcc}
\hline \multicolumn{1}{c}{ Model } & $\beta$ & Sig. \\
\hline (Constant) & 23,420 & 0,000 \\
Pertimbangan Pasar Kerja $\left(\mathrm{X}_{1}\right)$ & 0,334 & 0,019 \\
Lingkungan Kerja $\left(\mathrm{X}_{2}\right)$ & 2,709 & 0,000 \\
Personalitas $\left(\mathrm{X}_{3}\right)$ & 1,051 & 0,000 \\
Pertimbangan Pasar Kerja*Motivasi $\left(\mathrm{X}_{1}{ }^{*} \mathrm{M}\right)$ & 0,002 & 0,760 \\
Lingkungan Kerja*Motivasi $\left(\mathrm{X}_{2}{ }^{*} \mathrm{M}\right)$ & 0,103 & 0,000 \\
Personalitas*Motivasi $\left(\mathrm{X}_{3}{ }^{*} \mathrm{M}\right)$ & 0,029 & 0,035 \\
\hline
\end{tabular}

Sumber: Data Penelitian, 2020

Berdasarkan Tabel 9, nilai signifikasi $\mathrm{X}_{1}$ sebesar 0,019 lebih kecil dari 0,05, menunjukan variabel berpengaruh positif $Y\left(\mathrm{H}_{1}\right.$ diterima). Nilai signifikasi $\mathrm{X}_{2}$ sebesar 0,000 lebih kecil dari 0,05, menunjukan variabel berpengaruh positif $\mathrm{Y}\left(\mathrm{H}_{2}\right.$ diterima). Nilai signifikasi $X_{3}$ sebesar 0,000 lebih kecil dari 0,05, menunjukan variabel berpengaruh positif $\mathrm{Y}\left(\mathrm{H}_{3}\right.$ diterima). Nilai signifikasi $\mathrm{X}_{1}{ }^{*} \mathrm{M}$ sebesar 0,760 lebih besar dari 0,05 , menunjukan variabel berpengaruh negatif $\mathrm{Y}\left(\mathrm{H}_{4}\right.$ ditolak). Nilai signifikasi $\mathrm{X}_{2}{ }^{*} \mathrm{M}$ sebesar 0,000 lebih kecil dari 0,05, menunjukan variabel berpengaruh positif $\mathrm{Y}\left(\mathrm{H}_{5}\right.$ diterima). Nilai signifikasi $\mathrm{X}_{3}{ }^{*} \mathrm{M}$ sebesar 0,035 lebih kecil dari 0,05 , menunjukan variabel berpengaruh positif $\mathrm{Y}\left(\mathrm{H}_{6}\right.$ diterima).

\section{SIMPULAN}

Pertimbangan pasar kerja berpengaruh positif pada minat mahasiswa akuntansi menjadi akuntan publik. Semakin tinggi pertimbangan pasar kerja yang ada maka semakin tinggi minat mahasiswa akuntansi menjadi akuntan publik. Lingkungan kerja berpengaruh positif pada minat mahasiswa akuntansi menjadi akuntan publik. Semakin kondusif lingkungan kerja yang ada maka semakin tinggi minat mahasiswa akuntansi menjadi akuntan publik. Personalitas berpengaruh positif pada minat mahasiswa akuntansi menjadi akuntan publik. Semakin sesuai kondisi yang ada dengan personalitas maka semakin tinggi minat mahasiswa menjadi akuntan publik. Motivasi mampu memoderasi pengaruh lingkungan kerja dan personalitas pada minat mahasiswa akuntansi menjadi akuntan publik kecuali variabel pertimbangan pasar kerja. Semakin tinggi lingkungan kerja dan personalitas maka semakin tinggi minat mahasiswa akuntansi menjadi akuntan 
publik terutama yang memiliki motivasi tinggi, namun tidak berlaku pada variabel pertimbangan pasar kerja.

Penelitian ini hanya menggunakan variabel pertimbangan pasar kerja, lingkungan kerja dan personalitas dalam menentukan pengaruh minat mahasiswa akuntansi menjadi akuntan publik. Peneliti selanjutnya dapat menambah, mengganti atau menggunakan variabel lain yang lebih relevan seperti waktu dan biaya dalam menentukan minat mahasiswa akuntansi untuk menjadi akuntan publik.

\section{REFERENSI}

Ahmad, Z., Ismail, H., \& Anantharaman, R. N. (2015). To be or not to be: An investigation of accounting students' career intentions. Education and Training, 57(3), 360-376. https:// doi.org/10.1108/ET-03-2014-0025

Ajzen, I. (1991). The theory of planned behavior. Organizational Behavior and Human Decision Processes, 50(2), 179-211. https://doi.org/10.1016/07495978(91)90020-T

Alex, N. (2000). Manajemen Personalia: Manajemen Sumber Daya Manusia. Jakarta: Ghalia Indonesia.

Aziz, D. A., Ibrahim, M. A., Sidik, M. J., \& Tajuddin, M. (2017). Accounting Students' Perception and Their Intention To Become Professionally Qualified Accountants. SHS Web of Conferences, 8, 1-17. https:/ / doi.org/10.1051/

Bailey, T. H., \& Phillips, L. J. (2016). The influence of motivation and adaptation on students' subjective well-being, meaning in life and academic performance. Higher Education Research and Development, 35(2), 201-216. https:// doi.org/10.1080/07294360.2015.1087474

Caza, A., Brower, H. H., \& Wayne, J. H. (2015). Effects of a holistic, experiential curriculum on business students' satisfaction and career confidence. International Journal of Management Education, 13(1), 75-83. https:// doi.org/10.1016/j.ijme.2015.01.006

Chatman, J. A. (1989). Improving Interactional Organizational Research: A Model of Person-Organization Fit. The Academy of Management Review, 14(3), 333. https://doi.org/10.2307/258171

Dalc1, İ., \& Hasan, Ö. (2018). Cultural Values and Students' Intentions of Choosing Accounting Career. Journal of Financial Reporting and Accounting, 10(1), 73-94. Retrieved from http://dx.doi.org/10.1108/19852511211237453

Dewayani, M. A., Chasanah, C., \& Anam, M. S. (2017). Faktor-Faktor yang Memengaruhi Mahasiswa Akuntansi dalam Pemilihan Karir sebagai Akuntan Publik. Jurnal Analisis Bisnis Ekonomi, 15(2), 176-183. https:// doi.org/10.31603/bisnisekonomi.v15i2.1846

Dwisantoso, A. (2017). Analisi faktor-faktor yang mempengaruhi minat mahasiswa kauntansi berkarir menjadi akuntan publik.

Farag, M. S., \& Elias, R. Z. (2016). The relationship between accounting students' personality, professional skepticism and anticipatory socialization. Accounting Education, 25(2), 124-138. https://doi.org/10.1080/09639284.2015.1118639

Hastuti, D., \& Kartika, A. (2017). Faktor - Faktor Yang Mempengaruhi Minat Mahasiswa Akuntansi Uuntuk Berkarier Sebagai Akuntan Publik (Studi pada 
Mahasiswa Universitas Stikubank Semarang). Dinamika Akuntansi, Keuangan Dan Perbankan, 6(2), 127-139.

Hatane, S. E., Setiono, F. J., Setiawan, F. F., Semuel, H., \& Mangoting, Y. (2020). Learning environment, students' attitude and intention to enhance current knowledge in the context of choosing accounting career. Journal of Applied Research in Higher Education, (2011). https://doi.org/10.1108/JARHE-062019-0156

Irma, I., \& Hartati, N. (2019). The Effect of Motivation on the Interest of Accounting Students to Follow Accounting Professional Education. GATR Accounting and Finance Review, 4(3), 79-86. https:/ / doi.org/10.35609/afr.2019.4.3(3)

Irnasiwi, N. A. (2015). Faktor - Faktor Yang Berpengaruh Terhadap Minat Mahasiswa Akuntansi Untuk Berkarier Menjadi Akuntan Publik (Studi Empiris pada Mahasiswa Akuntansi Universitas Muhammadiyah Yogyakarta). UMY Repository, 53(9), 1689-1699. https:// doi.org/10.1017/CBO9781107415324.004

Juliansah, A., \& Suryaputri, R. V. (2016). Faktor-Faktor Yang Mempengaruhi Pemilihan Karir Sebagai Profesi Akuntan Publik Bagi Mahasiswa Akuntansi. Jurnal Akuntasi Trisakti (e-Journal), 3(2), 113-134.

Kirstein, M., Coetzee, S., \& Schmulian, A. (2019). Differences in accounting students' perceptions of their development of professional skills: A South African case. Higher Education, Skills and Work-Based Learning, 9(1), 41-59. https://doi.org/10.1108/HESWBL-04-2018-0051

Kudadiri, M. S., \& Hek, T. K. (2018). Faktor-Faktor Yang Mempengaruhi Keputusan Mahasiswa S-1 Kasus Mahasiswa S-1 Akuntansi IBBI ) Abstrak / Abstract. Jurnal Bina Akuntansi IBBI Volume 29 No.1 Juni 2018., 29(1), 79-89.

Lukman, H., \& Winata, S. (2017). Pemilihan Karir Sebagai Akuntan Publik Bagi Mahasiswa Perguruan Tinggi Swasta Dengan Pendekatan Theory of Planned Behaviour. Jurnal Akuntansi, 208. https:// doi.org/10.24912/ja.v21i2.195

Mazli. (2006). Persepsi Mahasiswa Akuntansi Mengenai Faktor-Faktor yang Mempengaruhi Pemilihan Karir. Penelitian Medan.

Muhamad, H., Salleh, M. M., \& Nordin, M. (2016). Factors influencing career choice of accounting students in University Putra Malaysia: qualitative pilot study. Journal of Advanced Research in Business and Management Studies, 5(1), 25-34.

Ng, Y.-H., Lai, S.-P., Su, Z.-P., Yap, J.-Y., Teoh, H.-Q., \& Lee, H. (2017). Factors influencing accounting students' career paths. Journal of Management Development, 36(3), 319-329. https:// doi.org/10.1108/JMD-11-2015-0169

Owusu, G. M. Y., Obeng, V. A., Ofori, C. G., Ossei Kwakye, T., \& Bekoe, R. A. (2018). What explains student's intentions to pursue a certified professional accountancy qualification? Meditari Accountancy Research, 26(2), 284-304. https:// doi.org/10.1108/MEDAR-06-2016-0065

Paramita, P. V. Y. S., \& Sari, M. M. R. (2019). Pengaruh Persepsi Mengenai Profesi Akuntan Publik, Motivasi, dan Kecerdasan Adversity Terhadap Minat Menjadi Akuntan Publik. E-Jurnal Akuntansi, 26, 146. https:// doi.org/10.24843/eja.2019.v26.i01.p06

Rahayu, P. N., \& Putra, N. W. A. (2019). Pengaruh Motivasi, Penghargaan 
Finansial, Pelatihan Profesional, Pertimbangan Pasar Kerja, Lingkungan Pada Karir Akuntan Publik. E-Jurnal Akuntansi, 28(2), 1200. https://doi.org/10.24843/eja.2019.v28.i02.p16

Robbins, S. P., \& Judge, T. A. (2017). Organizational Behavior, Global Edition. 747.

Saputra, I. H. (2011). Faktor-Faktor Yang Mempengaruhi Pemilihan Karir Mahasiswa Akuntansi Untuk Menjadi Akuntan Publik Di Perguruan Tinggi Swasta Wilayah Semarang. Universitas Dian Nuswantoro, (2003), 1-18.

Schoenfeld, J., Segal, G., \& Borgia, D. (2017). Social cognitive career theory and the goal of becoming a certified public accountant. Accounting Education, 26(2), 109-126. https:/ / doi.org/10.1080/09639284.2016.1274909

Sina, P. G. (2014). Motivasi Sebagai Penentu Perencanaan Keuangan (Suatu Studi Pustaka). Jurnal Ilmiah Akuntansi Dan Bisnis, 9(1), 42-48.

Sugiyono. (2017). Metode Penelitian Kuantitatif, Kualitatif, dan RED. Bandung: CV Alfabeta.

Suyono, N. A. (2014). Analisis Faktor-Faktor Yang Mempengaruhi Pemilihan Karir Sebagai Akuntan Publik (Studi Empiris Pada Mahasiswa Akuntansi Unsiq). Jurnal PPKM II, 69-83.

Ulfah, R., Amril Jaharadak, A., \& Khatibi, A. A. (2019). Motivational factors influencing MSU accounting students to become a certified public accountant (CPA). Management Science Letters, 9(10), 1675-1684. https://doi.org/10.5267/j.msl.2019.5.020

Wen, L., Yang, H. Chris, Bu, D., Diers, L., \& Wang, H. (2018). Public accounting vs private accounting, career choice of accounting students in China. Journal of Accounting in Emerging Economies, 8(1), 124-140. https://doi.org/10.1108/JAEE-09-2016-0080

Wheeler, K. G. (1983). Perceptions of labor market variables by college students in business, education, and psychology. Journal of Vocational Behavior, 22(1), 111. https:// doi.org/10.1016/0001-8791(83)90002-7 